\title{
Deformation Assisted Joining
}

Bay, N.; Alves, L. M.; Nielsen, C. V.; Silva, C. M. A. ; Martins, P. A. F.

Publication date:

2019

Document Version

Peer reviewed version

Link back to DTU Orbit

\section{Citation (APA):}

Bay, N., Alves, L. M., Nielsen, C. V., Silva, C. M. A., \& Martins, P. A. F. (2019). Deformation Assisted Joining. Abstract from 1st International Conference on Advanced Joining Processes, Ponta Delgada, Portugal.

\section{General rights}

Copyright and moral rights for the publications made accessible in the public portal are retained by the authors and/or other copyright owners and it is a condition of accessing publications that users recognise and abide by the legal requirements associated with these rights.

- Users may download and print one copy of any publication from the public portal for the purpose of private study or research.

- You may not further distribute the material or use it for any profit-making activity or commercial gain

- You may freely distribute the URL identifying the publication in the public portal

If you believe that this document breaches copyright please contact us providing details, and we will remove access to the work immediately and investigate your claim 


\title{
Deformation Assisted Joining
}

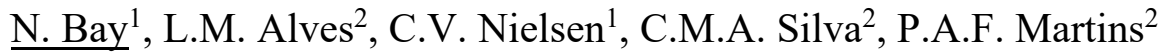 \\ ${ }^{1}$ Department of Mechanical Engineering, Technical University of Denmark \\ ${ }^{1}$ IDMEC, Instituto Superior Técnico, Universidade de Lisboa, 1049-001 Lisboa, Portugal
}

The large variety in new materials applied in industrial production and especially in automotive industry implies severe challenges to assembly operations. Material combinations such as high strength steel to itself, aluminium to itself, aluminium and magnesium alloys to steel and metals to sandwich materials and polymers are very difficult or impossible to join by welding. This has promoted the development of alternative methods of assembly. Among these methods an important group is deformation assisted joining. The paper categorizes these methods into the following types of joining mechanisms: 1. Mechanical joining including form-fit as well as force-fit (friction based) joints, 2. Solid phase welding and 3. Fusion welding combined with plastic deformation. Subsequently, the authors present their own developments of industrial application examples on each of the three types of assembly. Examples on mechanical form-fit joining are lap and T-joints of sheet by sheet-bulk forming and joining of tubes and tubes-to sheet by plastic instability and sheet-bulk forming. Examples on mechanical force-fit joints include bi-material coins with a polymer center and a surrounding metal ring and microjoining of a copper fork to a copper wire by resistance heating. Examples on solid phase welding include cold pressure welding of: aluminium alloy to mild steel by cross shear roll bonding for automotive slide bearings and end cap to thin walled aluminium container by ironing used for a liquid gas floater valve. Resistance welding of solid state joints are exemplified by projection welding of a steel flange to a tin-bronze tube for a thermostat valve, whereas combined fusion and solid state welding is obtained in automotive threesheet spot welding and projection welding of two sheets perpendicular to each other. Resistance projection welding of advanced high strength steels by introducing an intermediate donut shaped ring of mild steel and resistance spot welding of new, lightweight sandwich material with a polymer core by introducing a shunt tool to initiate the weld represent examples on fusion welding combined with plastic deformation. 